\title{
Kajian Impelementasi Quality Control Faktor Bright Band dan Atenuasi Radar Cuaca C-Band
}

\author{
Deffi M Putri $^{(\mathrm{a})^{*}}$, Eko Yulianto Nugroho ${ }^{(\mathrm{b})}$, dan Januar Rahmad Pratama ${ }^{(\mathrm{c})}$ \\ Stasiun Meteorologi Iskandar Kotawaringin Barat, Kalimantan Tengah, Indonesia, 74112 \\ Email : ${ }^{\left({ }^{*}\right)}$ deffi.munadiyat.putri@gmail.com, ${ }^{(b)}$ emplasemen@gmail.com, ${ }^{(c)}$ januar.hootowls@gmail.com
}

Diterima (10 November 2021), Direvisi (30 Januari 2021)

\begin{abstract}
Weather radars have several limitations there are bright band echoes and attenuation of electromagnetic wave from radar's beam. The purpose of this research is to conduct an analysis respect to the result of quality control from both of the limitations in 2019 which divide into four case study. Freezing level height of radiosonde used for support the identification activity of $B B C$ phenomena. The result of BBC can reduce the BBE patterns however, it unable to function optimally in reducing all parts of the BBE patterns. The correction of electromagnetic wave attenuation by rain particles using ZATC that has been done shows various results, either quantitatively or qualitatively. Attenuation correction is able to increase the rainfall value in product image SRI and PAC qualitatively. Quantitative analysis shows that the $r$ and MAE values after attenuation correction of hourly rainfall have a good result especially on November $22^{\text {nd }} 2019$ with $r$ and $M A E$ values of 0.91 and 2.38.The attenuation correction in daily rainfall data is able to improve the estimate by $62.5 \%$.
\end{abstract}

Keywords: attenuation, bright band echoes, QPE, radar.

Abstrak. Radar cuaca memiliki beberapa limitasi antara lain adanya bright band echoes serta atenuasi dari gelombang elektromagnetik yang dipancarkan oleh radar. Penelitian ini bertujuan untuk melakukan kegiatan analisis terhadap hasil kontrol kualitas pada dua jenis limitasi tersebut pada tahun 2019 yang terbagi kedalam empat studi kasus. Ketinggian freezing level radiosonde digunakan untuk mengidentifikasi lapisan melting layer serta pemanfaatan profil vertikal DVV dan VPR juga dilakukan untuk membantu kegiatan identifikasi fenomena BBC. Hasil BBC mampu mereduksi pola BBE namun, tidak mampu berfungsi secara optimal dalam mereduksi seluruh bagian dari pola BBE. Koreksi atenuasi gelombang elektromagnetik oleh partikel hujan menggunakan ZATC yang telah dilakukan menunjukan hasil yang bervariasi baik secara kualitatif maupun kuantitatif. Koreksi atenuasi secara kualitatif mampu meningkatkan nilai curah hujan pada citra produk SRI dan PAC. Analisis kuantitatif menunjukan bahwa nilai $r$ dan MAE setelah koreksi atenuasi dari curah hujan per jam memiliki nilai yang baik khususnya pada tanggal 22 November 2019 dengan nilai $r$ dan MAE yaitu 0.91 serta 2.38 . Koreksi atenuasi pada data curah hujan harian mampu memperbaiki estimasi sebesar $62.5 \%$.

Kata kunci: atenuasi, bright band echoes, QPE, radar

\section{PENDAHULUAN}

Hujan merupakan proses penting dalam siklus hidrologi di Bumi yang memiliki pengaruh signifikan terhadap sektor sosial dan ekonomi [1]. Radar cuaca telah digunakan secara luas untuk mendeteksi dan mengidentifikasi presipitasi serta mendukung kegiatan nowcast cuaca buruk selama lebih dari 50 tahun [2].Keuntungan dari penggunaan radar untuk estimasi hujan yaitu resolusi spasial dan temporal yang baik dan cakupan wilayah pengamatan yang lebih luas dibandingkan dengan penakar hujan konvensional [3]. 
Estimasi hujan pada radar sangat kompleks karena ketidakpastian dari pengaruh ground-clutter, partial beam blocking, pastial beam filling, variasi profil vertikal reflectivity, bias dari kalibrasi radar, atenuasi oleh radome [4]. Kondisi ini kemudian akan berpengaruh terhadap aplikasi hidrologi oleh citra radar yang membutuhkan estimasi hujan. Penggunaan radar dalam kuantifikasi hidrologi tidak akan bisa dilakukan jika tidak dilakukan koreksi terhadap bias [5].

Perubahan karakteristik hamburan dari pratikel presipitasi ditemukan pada wilayah dimana perubahan fase es menjadi tetes hujan terjadi, yaitu di wilayah melting layer [6]. Kajian tentang melting layer merupakan topik penting dalam fisika awan dan ilmu meteorologi [7]. Melting layer merupakan lapisan tipis dimana es berubah menjadi tetes hujan dan lapisan ini dapat diamati pada radar cuaca dimana fenomenanya disebut bright band [8]. Bright band (BB) merupakan sebuah lapisan dimana peningkatan reflectivity radar terjadi dan dikaitkan dengan melting layer serta dapat menjadi sumber utama overestimation dalam kegiatan quantitative precipitation estimation (QPE) [9]. Reflectivity dan kecepatan doppler merupakan parameter yang sesuai untuk identifikasi BB [10]. Pendekatan untuk deteksi dan koreksi BB terdiri dari berbagai macam metode salah satunya menggunakan vertical profiles of reflectivity (VPR) [11]. Profil vertikal dari doppler vertical velocity (DVV) juga dapat digunakan dalam mengidentifikasi fenomena ini dimana kecepatan jatuh partikel hidrometeor meningkat ketika partikel es mencair menjadi partikel air sehingga massa jenisnya menjadi lebih besar dengan koefisien drag yang menurun [10].

Hujan yang dipengaruhi oleh atenuasi merupakan sumber utama underestimation dalam kegiatan QPE pada C-band [12]. Data reflectivity radar digunakan sebagai prediksi atenuasi hujan [13]. Atenuasi sinyal merupakan fungsi dari panjang gelombang dimana radar dengan panjang gelombang yang lebih pendek akan mengalami atenuasi yang signifikan [14]. Peristiwa hujan melemahkan gelombang ketika gelombang tersebut bertemu dengan tetes hujan [15].

Penelitian ini akan melakukan proses kontrol kualitas produk radar khususnya pada proses pre-processing melalui bright band correction (BBC) dan Z-attenuation correction (ZATC). Kejadian hujan lebat di Stasiun Meteorologi Kotawaringin Barat digunakan sebagai studi kasus untuk penelitian ini. Studi kasus terbagi kedalam tanggal 16 April, 27 April, 22 November dan 30 Desember tahun 2019.

\section{METODOLOGI PENELITIAN}

Wilayah penelitian mencakup Kabupaten Kotawaringin Barat yang difokuskan pada titik radar cuaca dan beberapa titik pada Gambar 1. Penelitian ini menggunakan jenis data primer yaitu data curah hujan per jam dan per hari, data udara atas serta data radar cuaca dalam bentuk volumetrik. Spesifikasi dari data yang digunakan dalam proses analisis terdapat pada Tabel 1. Kemudian untuk alur penelitian ditunjukkan pada Gambar 2.

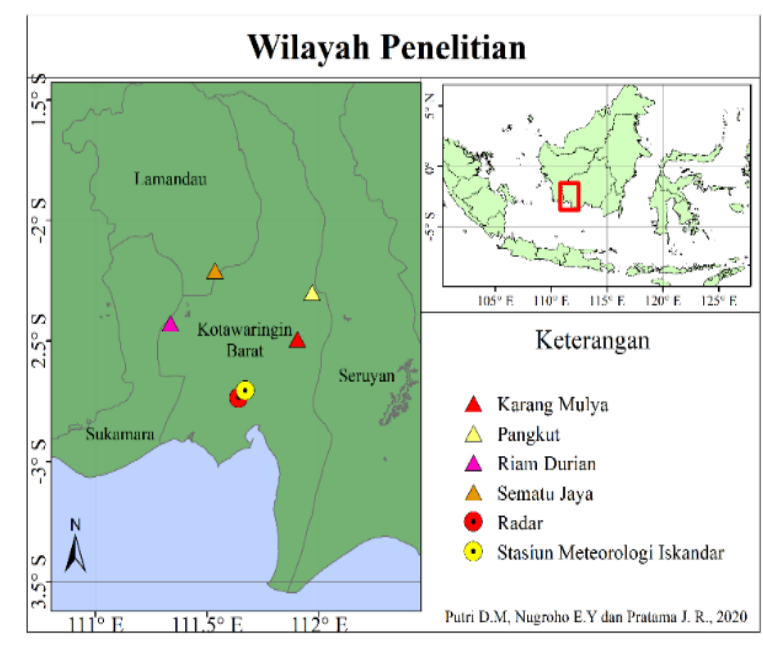

Gambar 1. Wilayah penelitian 


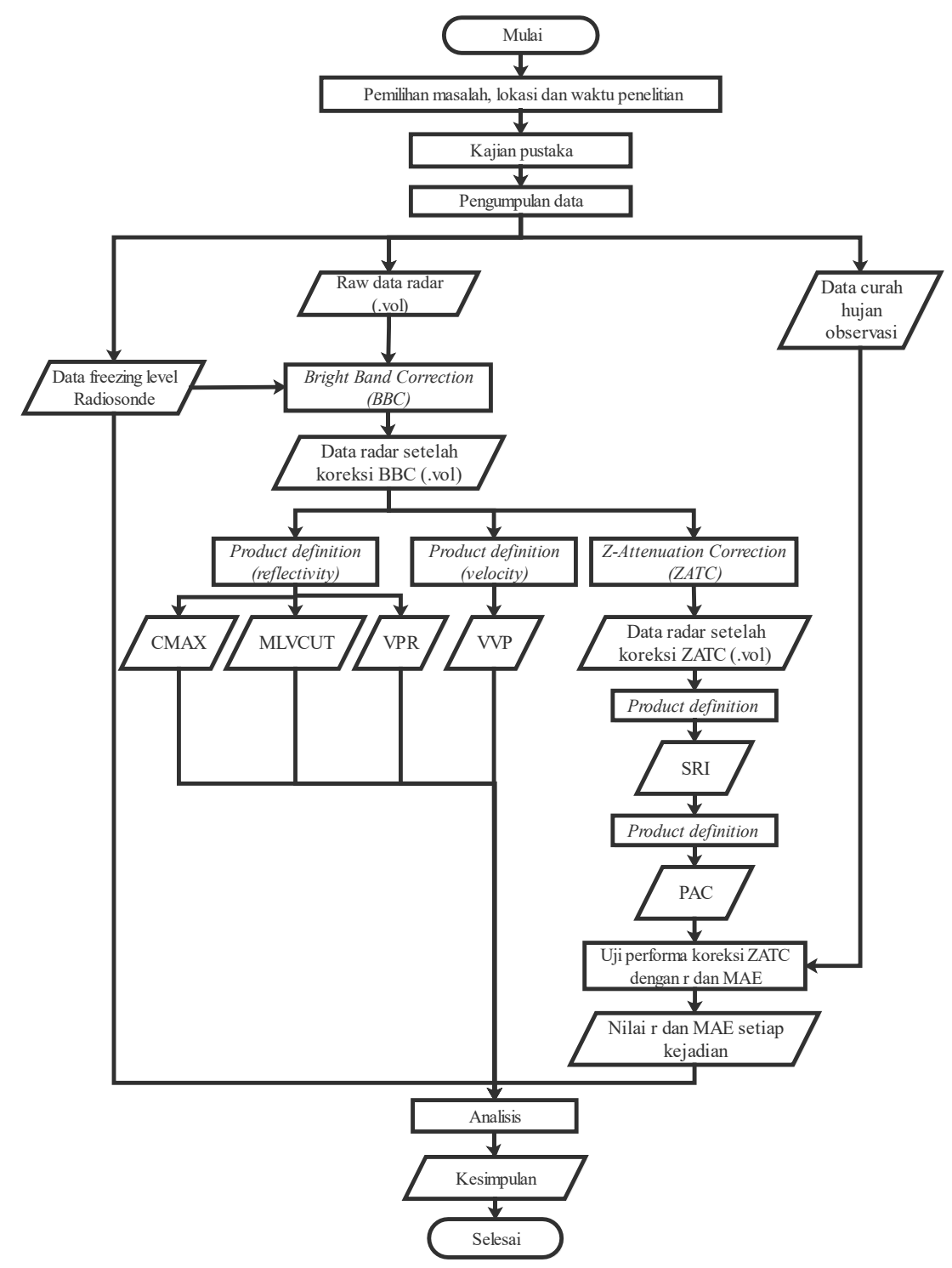

Gambar 2. Diagram alur penelitian

Tabel 1. Spesifikasi data

\begin{tabular}{|c|c|c|c|}
\hline Jenis Data & $\begin{array}{c}\text { Resolusi } \\
\text { Temporal } \\
\end{array}$ & Ekstensi & Instrumen \\
\hline Curah hujan & 1 jam & .xlsx & Hillman \\
\hline Curah hujan & 24 jam & .xlsx & Obs \\
\hline Udara atas & $12 \mathrm{jam}$ & .txt & Radiosonde \\
\hline Radar cuaca & 10 menit & .vol & $\begin{array}{c}\text { Radar cuaca } \\
\text { C-Band }\end{array}$ \\
\hline
\end{tabular}

Penelitian ini terbagi kedalam dua bagian yaitu koreksi BBE dan ZATC. Data radar volumetrik diolah menggunakan perangkat lunak Rainbow 5.49. Identifikasi pola BBE dilakukan melalui produk reflectivity untuk mendapatkan kasus dengan BBE. Pengaturan kontrol kualitas dilakukan pada tahap pre-processing dengan menyesuaikan batas atas dan bawah BBE dengan data freezing level dari pengamatan Radiosonde. Posisi melting layer dapat diketahui melalui kajian profil suhu vertikal yang didapatkan melalui data radiosonde atau model cuaca numerik [7]. Analisis pada penelitian ini terdapat dua jenis yaitu analisis kuantitatif dan kualitatif pada BBE dan ZATC. Produk yang digunakan dalam mendukung analisis kualitatif BBE yaitu produk Column Maximum (CMAX) dan Vertical Cut (VCUT) dari data reflectivity. Analisis kuantitatif BBE menggunakan data 
freezing level serta VPR dan DVV dengan pola analisis sesuai dengan penelitian [10] pada Gambar 3. Analisis kualitatif ZATC dilakukan dengan mempertimbangkan perubahan pola dari citra produk SRI dan PAC selain itu analisis kuantitatif dilakukan dengan membandingkan curah hujan perjam antara data hujan pengukuran, non quality control (Non-QC) dan yang telah dilakukan quality control (QC). Perbandingan hasil diukur menggunakan koefisien korelasi Pearson (Persamaan 1) dan Mean Absolute Error (MAE) (Persamaan 2).

$$
r=\frac{\sum_{i}^{n} x_{i} y_{i}-\frac{1}{n}\left(\sum_{i=1}^{n} x_{i}\right)\left(\sum_{i=1}^{n} y_{i}\right)}{\sqrt{\left[\sum_{i=1}^{n} x^{2}-\frac{1}{n}\left(\sum_{i=1}^{n} x_{i}\right)^{2}\right] \sqrt{\left[\sum_{i=1}^{n} y^{2}-\frac{1}{n}\left(\sum_{i=1}^{n} y_{i}\right)^{2}\right]}}}
$$

Dimana $\mathrm{r}$ adalah koefisien korelasi, $\mathrm{x}_{\mathrm{i}}$ adalah QPE radar ke-i $(\mathrm{mm}), \mathrm{y}_{\mathrm{i}}$ adalah curah hujan observasi penakar hujan $(\mathrm{mm})$ dan $\mathrm{n}$ adalah jumlah data.

$$
M A E=\frac{1}{n} \sum_{i=1}^{n}\left(f_{i}-O_{i}\right)
$$

Dengan MAE adalah koefisien korelasi, $\mathrm{f}_{\mathrm{i}}$ adalah QPE radar ke-i $(\mathrm{mm}), \mathrm{o}_{\mathrm{i}}$ adalah curah hujan observasi penakar hujan $(\mathrm{mm})$ dan $\mathrm{n}$ adalah jumlah data

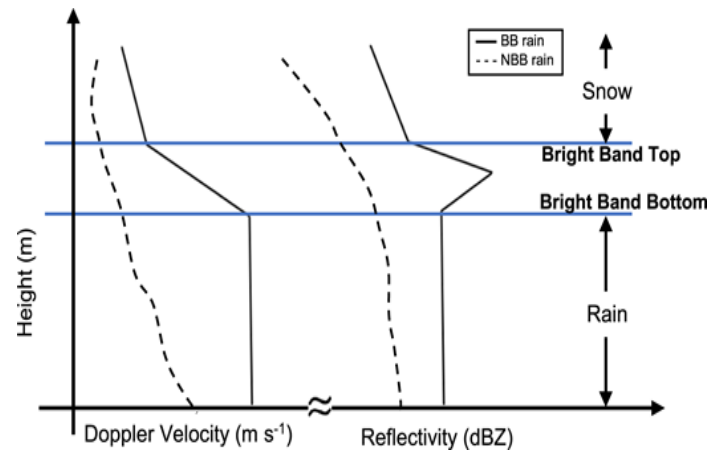

Gambar 3. Skema ideal profil vertikal DVV dan VPR [10]

\section{HASIL DAN PEMBAHASAN}

\section{Identifikasi Bright Band Echoes}

Ketinggian freezing level merujuk pada ketinggian dimana suhu bernilai $0^{\circ} \mathrm{C}$ di atmosfer [16]. Ketinggian freezing level terhadap kasus hujan sedang-lebat di Kotawaringin Barat memiliki nilai yang bervariasi. Ketinggian freezing level ditunjukan oleh Gambar 4. dengan rata-rata ketinggian sebesar 5.057,9 meter. Wilayah yang diarsir menggunakan warna abu-abu menunjukan jangkauan ketinggian melting layer dalam konfigurasi BBC sedangkan garis biru merupakan nilai sebenarnya dari freezing level pada pengamatan udara atas. Konfigurasi melting layer pada $\mathrm{BBC}$ telah mencakup freezing level.

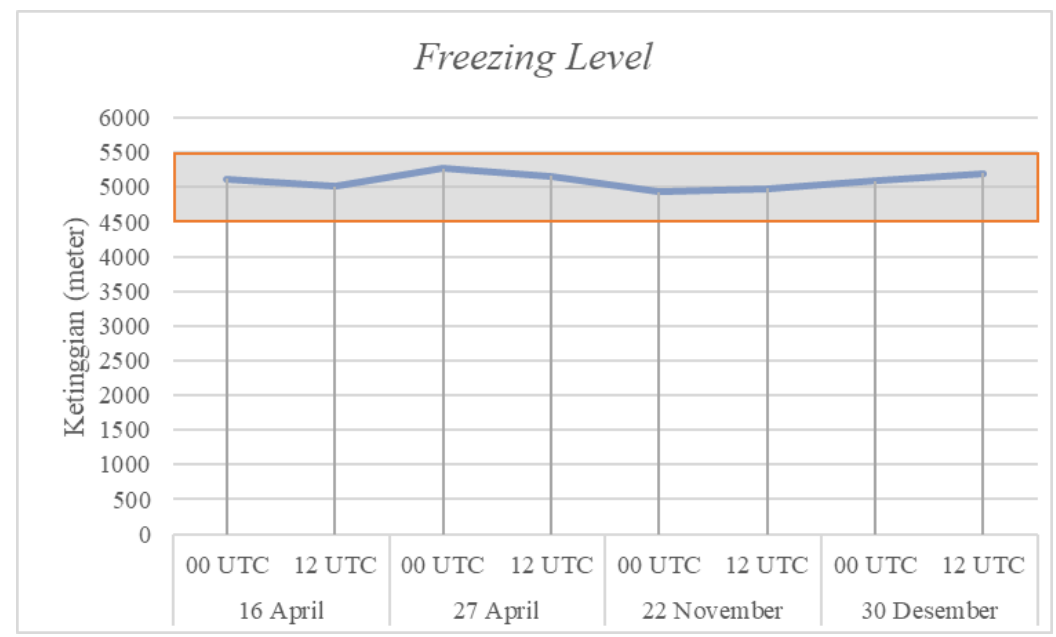

Gambar 4. Ketinggian freezing level Radiosonde 


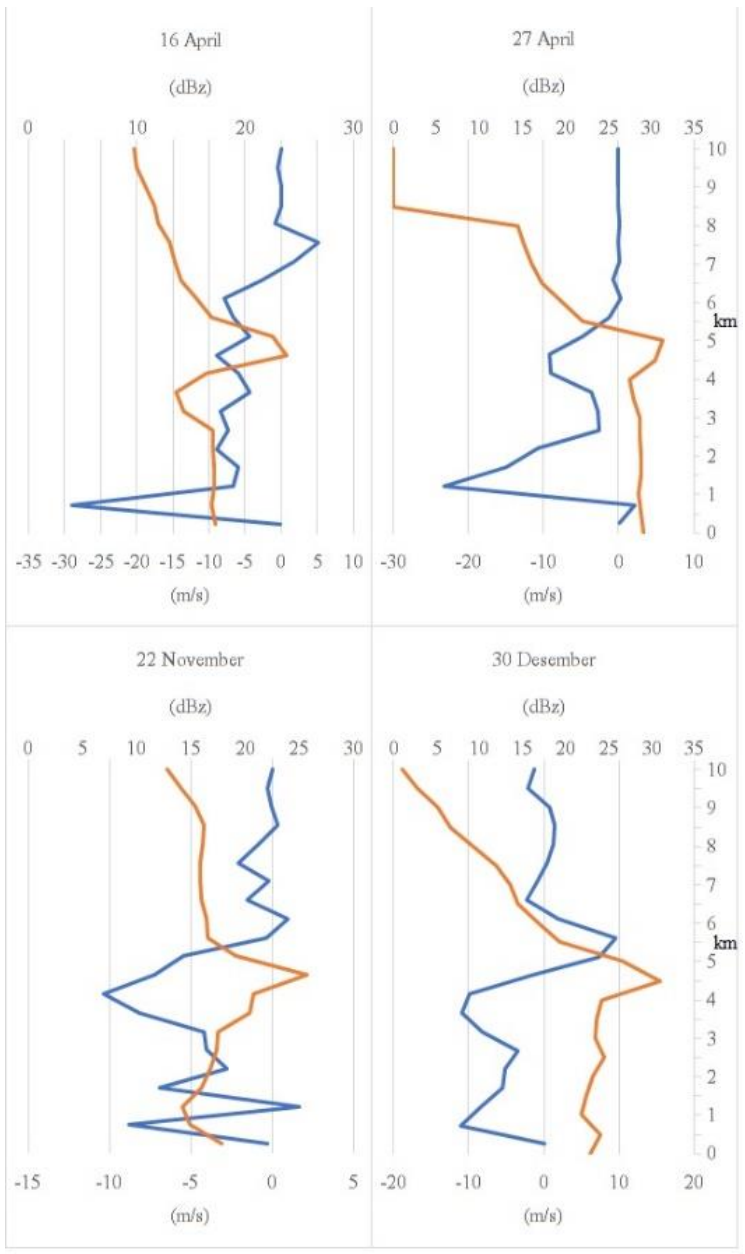

Gambar 5. Profil vertikal kecepatan dan reflectivity Non-QC (garis biru: DVV, garis jingga: VPR)

Analisis BBE menggunakan profil vertikal dari parameter kecepatan dan reflectivity menunjukan pola yang sama pada semua kasus. Nilai reflectivity maksimum tercapai pada melting layer dan kemudian mengalami penurunan serta perubahan secara fluktuatif. Kecepatan jatuh dari partikel hidrometeor mulai meningkat secara signifikan pada melting layer ketika partikel es mencair dan menjadi lebih berat [10]. Kondisi ini diketahui melalui perubahan nilai profil kecepatan menjadi nilai negatif yang semakin menguat. Profil kecepatan diatas melting layer memiliki kecepatan turun yang lambat relatif terhadap partikel hidrometeor di bawah BB [17]. Grafik pada Gambar 5 dapat membantu dalam identifikasi ketebalan lapisan BBE. Keempat studi kasus memperlihatkan adanya hubungan antara peningkatan kecepatan turun dari partikel hidrometeor dan peningkatan reflectivity pada lapisan antara 4 hingga $5.5 \mathrm{~km}$. Hasil ini sesuai dengan profil freezing level dari observasi udara atas.

\section{Analisis Kualitatif Distribusi Spasial Horisontal dan Vertikal Bright Band Correction}

Analisis kualitatif terbagi kedalam dua jenis yaitu analisis distribusi horisontal dan vertikal dari reflectivity. Analisis kualitatif spasial horisontal terhadap produk CMAX secara umum menunjukan adanya perubahan pada pola reflectivity setelah dilakukan koreksi (Gambar 6). BBE terdiri dari beberapa ring yang berada pada level ketinggian berbeda berdasarkan citra produk VCUT. Hasil menunjukan bahwa BBC tidak dapat melakukan filter terhadap seluruh pola BBE yang terdapat pada citra radar akan tetapi dapat mengurangi potensi estimasi reflectivity yang berlebihan (overestimation) pada kegiatan interpretasi. 
Deffi M Putri: Kajian Implementasi Quality Control Faktor Bright Band dan Atenuasi Radar Cuaca CBand

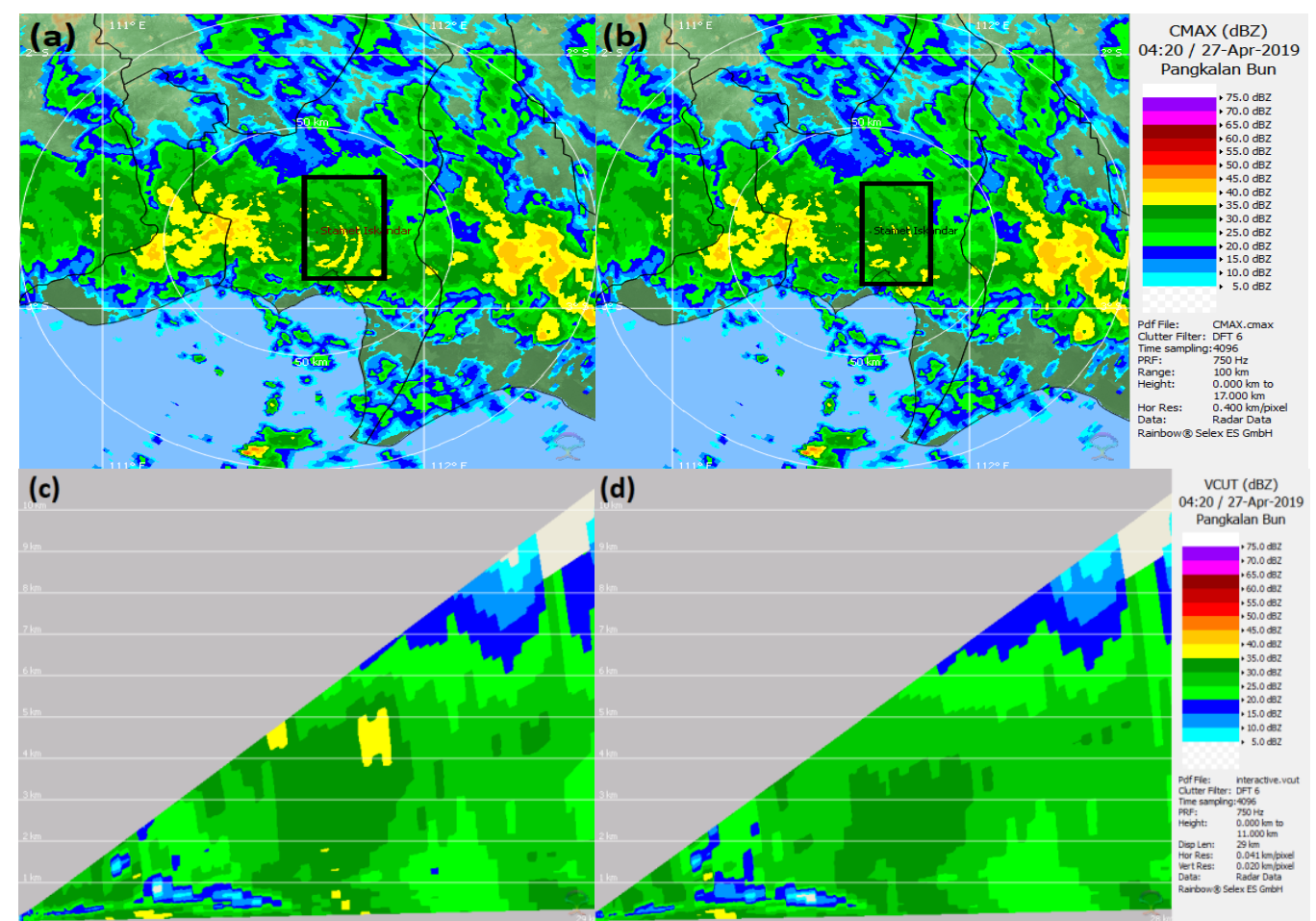

Gambar 6. Perbandingan produk (a) CMAX Non-QC dan (b)CMAX QC; (c) VCUT Non-QC dan (d) VCUT QC pada kasus 27 April 2019

Analisis Kualitatif distribusi Spasial horizontal Z-based Attenuation Correction

Citra radar yang telah dilakukan ZATC pada kedua produk SRI dan PAC menunjukan intensitas dan pola spasial yang berbeda. Analisis kualitatif terhadap citra
SRI dan PAC secara spasial menunjukan bahwa ZATC mampu meningkatkan intensitas hujan. Gambar 8 memvisualisasikan perubahan dan penguatan nilai baik intensitas maupun akumulasi curah hujan serta terdapat adanya perubahan pola.

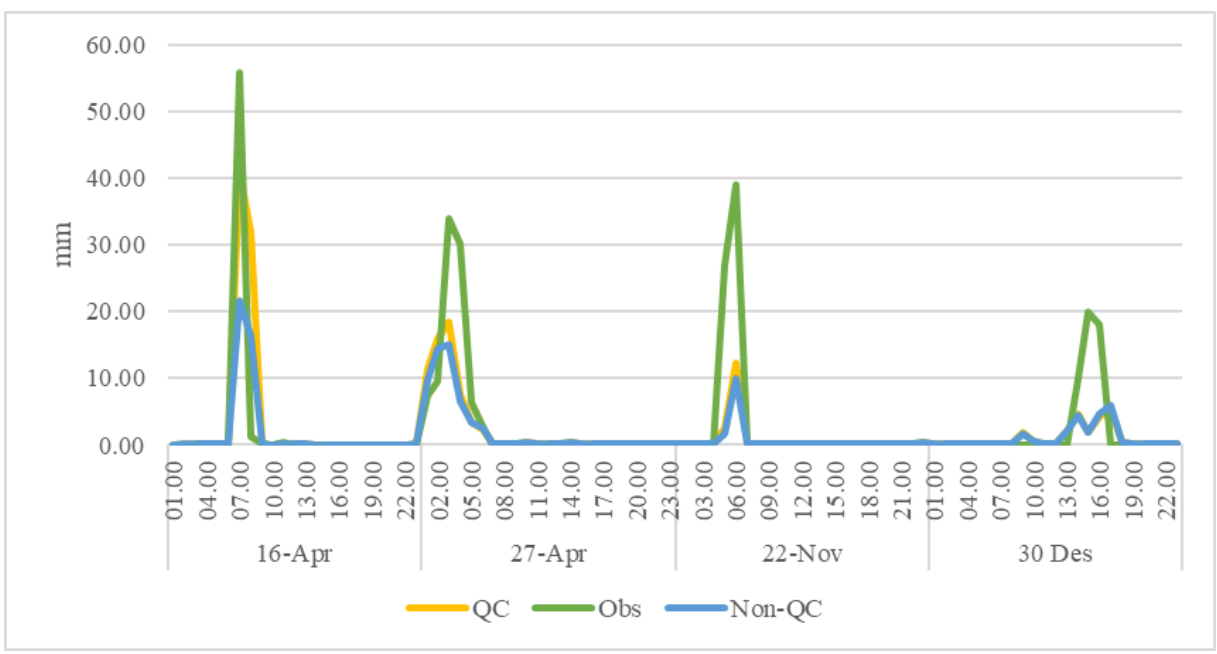

Gambar 7. Grafik perbandingan curah hujan Non-QC dan QC terhadap penakar hujan 


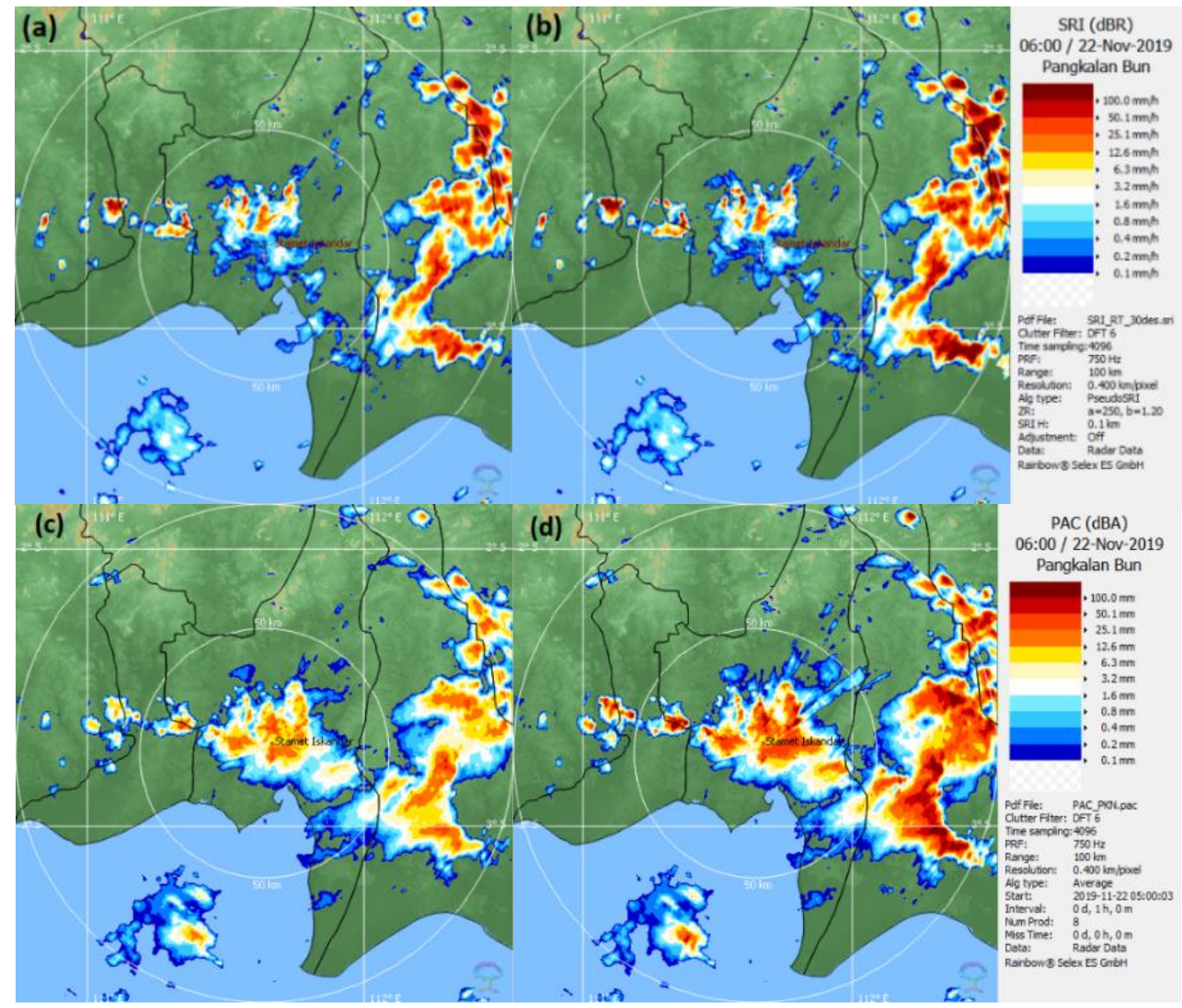

Gambar 8. Perbandingan produk (a) SRI Non-QC dan (b) SRI QC; (c) PAC Non-QC dan (d) PAC QC pada kasus 22 November 2019

\section{Analisis Kuantitatif Z-based Attenuation Correction}

Time series QPE radar terhadap curah hujan observasi Stasiun Meteorologi Iskandar disajikan pada Gambar 7 yang terbagi kedalam tiga jenis data yaitu curah hujan observasi, QC dan Non-QC. QPE kedua jenis radar secara umum menunjukan hasil yang underestimate. Pola QPE radar dapat merepresentasikan waktu terjadinya hujan dengan baik sesuai hasil observasi.
Ketersediaan data yang real time serta resolusi yang tinggi dari radar merupakan fitur menarik untuk aplikasi prediksi dan prakiraan hidrologi menggunakan model terdistribusi, namun data yang diperoleh tetap menjadi sumber ketidakpastian yang penting untuk prediksi hidrologi [18]. MAE digunakan untuk mengukur tingkat keakuratan suatu model peramalan. Dengan merepresentasikan rata - rata galat absolut antara hasil peramalan dengan nilai sebenarnya [19].

Tabel 2. Verifikasi ZATC

\begin{tabular}{ccccccccc}
\hline & \multicolumn{2}{c}{16 April } & \multicolumn{2}{c}{ 27 April } & \multicolumn{2}{c}{ 22 November } & \multicolumn{2}{c}{ 30 Desember } \\
\cline { 2 - 9 } & $\mathrm{r}$ & MAE & $\mathrm{r}$ & MAE & $\mathrm{r}$ & MAE & $\mathrm{r}$ & MAE \\
\hline Non-QC & 0.80 & 2.22 & 0.78 & 2.45 & 0.89 & 2.51 & 0.54 & 2.21 \\
\hline QC & 0.79 & 2.06 & 0.80 & 2.40 & 0.91 & 2.38 & 0.55 & 2.21 \\
\hline
\end{tabular}


Deffi M Putri: Kajian Implementasi Quality Control Faktor Bright Band dan Atenuasi Radar Cuaca C-

Band

Tabel 3. Selisih total curah hujan harian pengamatan dengan data radar pada empat pos hujan

\begin{tabular}{ccccccccc}
\hline & \multicolumn{4}{c}{ Non-QC } & \multicolumn{4}{c}{ QC } \\
\cline { 2 - 9 } & 16 Apr & 27 Apr & 22 Nov & 30 Des & 16 Apr & 27 Apr & 22 Nov & 30 Des \\
\hline Karang Mulya & 6.6 & -44.1 & -6.7 & -39.1 & 8.7 & -41.6 & -5.5 & -36.8 \\
Pangkut & 4.1 & -16.9 & 1.0 & -9.0 & 6.3 & -16.7 & 1.0 & -2.7 \\
Riam Durian & 1.2 & -22.0 & 3.5 & -47.5 & 1.7 & -21.3 & 3.5 & -43.8 \\
Sematu Jaya & -12.6 & -6.9 & 1.3 & -43.4 & -9.2 & -5.2 & 1.5 & -43.2 \\
\hline
\end{tabular}

Berdasarkan analisis validasi pada produk Non-QC dan QC terhadap data curah hujan Tabel 2 menunjukan bahwa performa QC memperbaiki produk radar semua studi kasus. Ketidakberhasilan yang sangat signifikan implementasi QC terjadi pada kasus 1. QPE yang ditunjukan oleh Non-QC dan QC secara umum memiliki hasil yang underestimate. QPE radar pada kasus 4 memiliki korelasi yang rendah relatif dibandingkan dengan kasus lainnya. Hal tersebut disebabkan oleh ketidakmampuan QPE radar dalam mengimitasi pola hujan observasi. Selisih jumlah total curah hujan harian pengamatan terhadap QPE radar pada empat pos hujan yang terdapat dalam Tabel 3 menunjukan tiga jenis hasil yang berbeda setelah dilakukan QC. Tabel berwarna biru dengan prosentase $12.5 \%$ tidak mengindikasikan adanya perbaikan kualitas QPE setelah kegiatan QC. Tabel berwarna jingga menunjukan bahwa kegiatan QC tidak berpengaruh terhadap perbaikan QPE radar dengan prosentase $25 \%$ namun sebaliknya, tabel tanpa warna mampu menunjukan bahwa QC mampu memperbaiki kualitas QPE yang dimiliki oleh radar dengan prosentase sebesar $62.5 \%$. Kesalahan QPE oleh radar dapat disebabkan oleh perbedaan peralatan dan perbedaan algoritma deteksi terjadinya hujan antara penakar hujan dengan radar, selain itu arah dan kecepatan angin permukaan dapat berpengaruh terhadap hujan yang jatuh ke permukaan.

\section{KESIMPULAN}

Radar dapat membantu dalam proses estimasi hujan untuk berbagai kepentingan. Bright band echoes merupakan salah satu limitasi radar cuaca yang dapat menurunkan akurasi dari interpretasi citra radar. BBE terjadi karena perubahan fase partikel dari es menjadi air. Identifikasi BBE dapat dilakukan dengan mengkaji nilai kecepatan turun partikel serta profil vertikal reflectivity melalui produk DVV dan VPR. Kecepatan turun serta nilai reflectivity partikel meningkat pada lapisan melting layer menurut analisis profil DVV dan VPR dengan ketinggian antara 4.5 hingga $5.5 \mathrm{~km}$. Lapisan ini merupakan lapisan yang dianalisis serta dilakukan BBC. BBC yang telah dilakukan memiliki hasil yang bervariasi. BBC tidak dapat secara optimal mereduksi estimasi berlebih pada citra reflectivity dari radar cuaca akibat fenomena BBE.

Radar cuaca dapat membantu dalam menganalisis proses hidrologi yaitu hujan melalui estimasi curah hujan dengan hubungan Z-R. Gelombang elektromagnetik yang dipancarakan oleh radar akan mengalami atenuasi seiring dengan peningkatan frekuensi dari gelombang tersebut. Kegiatan ZATC dilakukan untuk meningkatkan performa estimasi citra radar secara kualitatif dan kuantitatif serta dalam cakupan temporal maupun spasial. Analisis menunjukan bahwa ZATC mampu memperbaiki kualitas estimasi citra radar sebesar $62.5 \%$ sedangkan $25 \%$ dari hasil 
tidak menunjukan perubahan setelah dilakukan kontrol kualitas. Hasil koreksi terbaik ditunjukan oleh tanggal 22 November 2019 yaitu adanya perbaikan terhadap nilai curah hujan dengan nilai $r$ 0.91 dan MAE 2.38.

\section{DAFTAR PUSTAKA}

[1] R. K. Sumesh, E. A. Resmi, C. K. Unnikrishnan, D. Jash, T. S. Sreekanth, M. C. Mol Resmi, K. Rajeevan, S. Nita dan K. K. Ramachandran., "Microphysical Aspects of Tropical Rainfall During Bright Band Events at Mid and HighAltitude Regions Over Southern Western Ghats, India", Atmos. Res., vol. 227, no. May, pp. 178-197, 2019, doi: 10.1016/j.atmosres.2019.05.002.

[2] E. Saltikoff, K. Friedrich, J, Soderholm, K. Lengfeld, B. Nelson, A. Becker, R. Hollmann, B. Urban, Heistermann, dan C. Tassone et al., "An Overview of Using Weather Radar for Climatological Studies Successes, Challenges, and Potential", Bull. Am. Meteorol. Soc., vol. 100, no. 9, pp. 1739-1751, 2019, doi: 10.1175/BAMS-D-18-0166.1.

[3] X. He, T. O. Sonnenborg, J. C. Refsgaard, F. Vejen, dan K. H. Jensen, "Evaluation of the Value of Radar QPE Data and Rain Gauge Data for Hydrological Modeling", Water Resour. Res., vol. 49, no. 9, pp. 5989-6005, 2013, doi: 10.1002/wrcr.20471.

[4] J. Figueras i Ventura, A. A. Boumahmoud, B. Fradon, P. Dupuy, dan P. Tabary, "Long-term Monitoring of French Polarimetric Radar Data Quality and Evaluation of Several Polarimetric Quantitative Precipitation Estimators in Ideal Conditions for Operational Implementation at C-band”,
Quarterly Journal of the Royal Meteorological Society, vol. 138, no. 669. pp. 2212-2228, 2012, doi: 10.1002/qj.1934.

[5] P. Tabary, A. A. Boumahmoud, H. Andrieu, R. J. Thompson, A. J. Illingworth, E. Le Bouar, dan J. Testud, "Evaluation of Two 'Integrated' Polarimetric Quantitative Precipitation Estimation (QPE) Algorithms at C-band", J. Hydrol., vol. 405, no. 3-4, pp. 248-260, 2011, doi: 10.1016/j.jhydrol.2011.05.021.

[6] P. Di Girolamo, D. Summa, M. Cacciani, E. G. Norton, G. Peters, dan Y. Dufournet, "Lidar and Radar Measurements of the Melting Layer: Observations of Dark and Bright Band Phenomena", Atmospheric Chemistry and Physics, vol. 12, no. 9. pp. 4143-4157, 2012, doi: 10.5194/acp-12-4143-2012.

[7] T. Islam, M. A. Rico-Ramirez, D. Han, M. Bray, dan P. K. Srivastava, "Fuzzy Logic Based Melting Layer Recognition from $3 \mathrm{GHz}$ Dual Polarization Radar: Appraisal with NWP Model and Radio Sounding observations", Theor. Appl. Climatol., vol. 112, no. 1-2, pp. 317338, 2013, doi: 10.1007/s00704-0120721-z.

[8] H. Li and D. Moisseev, "Two Layers of Melting Ice Particles Within a Single Radar Bright Band: Interpretation dan Implications", Geophys. Res. Lett., vol. 47, no. 13, pp. 1-10, 2020, doi: 10.1029/2020GL087499.

[9] Y. Cao, D. Su, X. Fan, dan H. Chen, "Evaluating the Algorithm for Correction of the Bright Band Effects in QPEs with S-, C- dan X-Band Dual-Polarized Radars," Adv. Atmos. Sci., vol. 36, no. 1, pp. 41-54, 2019, doi: 10.1007/s00376-018-8032-7.

[10] D. Lin, B. E. N. Pickering, dan R. R. 
Neely, "Relating the Radar Bright Band and its Strength to surface Rainfall Rate Using an Automated Approach", J. Hydrometeorol., vol. 21, no. 2, pp. 335-353, 2020, doi: 10.1175/JHM-D-19-0085.1.

[11] T. Pfaff, A. Engelbrecht, dan J. Seidel, "Detection of the Bright Band With a Vertically Pointing K-band Radar," Meteorol. Zeitschrift, vol. 23, no. 5, pp. 527-534, 2014, doi: 10.1127/metz/2014/0605.

[12] S. Jacobi dan M. Heistermann, "Benchmarking Attenuation Correction Procedures for Six Years of Single-Polarized C-Band Weather Radar Observations in South-West Germany", Geomatics, Nat. Hazards Risk, vol. 7, no. 6, pp. 1785-1799, 2016, doi: 10.1080/19475705.2016.1155080.

[13] J. X. Yeo, Y. H. Lee, dan J. T. Ong, "Radar Measured Rain Attenuation with Proposed Z-R Relationship at a Tropical Location," AEU - Int. J. Electron. Commun., vol. 69, no. 1, pp. 458-461, 2015, doi: 10.1016/j.aeue.2014.10.010.

[14] J. Y. Gu, A. Ryzhkov, P. Zhang, P. Neilley, M. Knight, B. Wolf dan D. I. Lee, "Polarimetric Attenuation Correction in Heavy Rain at C band," J. Appl. Meteorol. Climatol., vol. 50, no. 1, pp. 39-58, 2011, doi: 10.1175/2010JAMC2258.1.

[15] Y. Xue, X. C. Liu, T. C. Gao, C. Y.
Yang, dan K. Song, "Regional Attenuation Correction of Weather Radar Using a Distributed Microwave-Links Network", $A d v$. Meteorol., vol. 2017, 2017, doi: $10.1155 / 2017 / 8621239$.

[16] E. O. Olurotimi, O. Sokoya, J. S. Ojo, dan P. A. Owolawi, "Observation of Bright-Band Height Data From TRMM-PR for Satellite Communication in South Africa", $J$. Atmos. Solar-Terrestrial Phys., vol. 160, pp. 24-33, 2017, doi: 10.1016/j.jastp.2017.05.004.

[17] A. E. Emory, B. Demoz, K. Vermeesch, dan M. Hicks, "Double Bright Band Observations with HighResolution Vertically Pointing Radar, Lidar, and Profilers", Journal of Geophysical Research, vol. 119, no. 13. pp. 8201-8211, 2014, doi: 10.1002/2013JD020063.

[18] K. Schröter, X. Llort, C. VelascoForero, M. Ostrowski, dan D. Sempere-Torres, "Implications of Radar Rainfall Estimates Uncertainty on Distributed Hydrological Model Predictions", Atmos. Res., vol. 100, no. 2-3, pp. 237-245, 2011, doi: 10.1016/j.atmosres.2010.08.014.

[19] A. A. Suryanto, "Penerapan Metode Mean Absolute Error (Mea) Dalam Algoritma Regresi Linear Untuk Prediksi Produksi Padi", Saintekbu, vol. 11, no. 1, pp. 78-83, 2019, doi: 10.32764/saintekbu.v11i1.298. 